\title{
Multiplikasi Eksplan Tunas Anggrek Hitam (Coelogyne pandurata Lindl.) dengan Penambahan NAA (Naphthalene Acetic Acid) dan Ekstrak Biji Jagung (Zea mays) Secara In Vitro
}

\section{(In Vitro Multiplication of Black Orchid Buds (Coelogyne pandurata Lindl.) With The Addition NAA (Naphthalene Acetic Acid) and Corn (Zea mays) Seed Extract)}

\author{
Nurkapita*, Riza Linda, Zulfa Zakiah \\ Universitas Tanjungpura; Jl. Prof. Dr. H. Hadari Nawawi, Pontianak \\ Program Studi Biologi, Jurusan Biologi FMIPA Untan Kalimantan Barat 78124 \\ *Email Korespondensi: Nurkapita260717@gmail.com
}

(Article History: Received February 18, 2021; Revised April 27, 2021; Accepted May 19, 2021)

\begin{abstract}
ABSTRAK
Perkembangbiakan anggrek secara generatif alami membutuhkan bantuan jamur mikoriza untuk perkecambahan biji, sedangkan usaha perbanyakan konvensional memerlukan waktu lama untuk memperoleh tanaman dalam jumlah banyak. Salah satu alternatif untuk perbanyakan anggrek hitam (Coelogyne pandurata Lindl.) adalah melalui multiplikasi tunas anggrek secara in vitro. Tujuan penelitian adalah untuk membuktikan pengaruh pemberian NAA (Naphthalene Acetic Acid) dan ekstrak biji jagung (Zea mays) terhadap multiplikasi tunas anggrek hitam. Penelitian dilakukan di Laboratorium Kultur Jaringan Jurusan Biologi Fakultas Matematika dan Ilmu Pengetahuan Alam Universitas Tanjungpura Pontianak. Penelitian ini menggunakan Rancangan Acak Lengkap (RAL) pola faktorial dengan dua faktor perlakuan. Faktor pertama adalah NAA terdiri dari 5 taraf konsentrasi yaitu $A_{0}\left(0 \mathrm{M} /\right.$ kontrol) $A_{1}\left(10^{-7} \mathrm{M}\right), A_{2}\left(10^{-6} \mathrm{M}\right), A_{3}\left(5 \times 10^{-7} \mathrm{M}\right)$ dan $A_{4}\left(5 \times 10^{-6} \mathrm{M}\right)$ dan faktor ekstrak biji jagung $(B)$ dengan 5 taraf konsentrasi yaitu $B_{0}(0 \%), B_{1}(2,5 \%), B_{2}(5 \%) ; B_{3}(7,5 \%)$ dan $B_{4}(10 \%)$. Pemberian kombinasi NAA dan ekstrak biji jagung berpengaruh nyata terhadap semua parameter yaitu jumlah tunas, jumlah daun, dan tinggi tunas. Hasil terbaik rerata jumlah tunas pada perlakuan $A_{4}+B_{4}$ yaitu $5 \times 10^{-6} \mathrm{M} N A A+10 \%$ ekstrak biji jagung. Hasil terbaik pada rerata jumlah daun pada perlakuan $A_{2}+B_{2}$ yaitu $5 \times 10^{-7} M N A A+5 \%$ ekstrak biji jagung dan hasil terbaik pada rerata tinggi tunas pada perlakuan $A_{1}+B_{1}$ yaitu $10^{-7} M N A A+2,5 \%$ ekstrak biji jagung.

Kata Kunci: multiplikasi; tunas anggrek hitam; ekstrak biji jagung; NAA.
\end{abstract}

\section{ABSTRACT}

Generative reproduction of orchid plants it takes a requires the help of mycorriza mushrooms for seed germination, whereas conventional propagation business takes a long time to obtain large quantities of plants. One alternative to the propagation black orchids (Coelogyne pandurata Lindl.) is required through tissue culture techniques. The purpose of this study is to find the influence and concentration corn seed extract (Zea mays) and NAA (Naphthalene Acetic Acid) on the multiplication black orchids. This research was conducted in the tissue culture laboratory Biology Department Faculty of Mathematics and Natural Sciences Tanjungpura University Pontianak. The study used a Complete Randomized Design (RAL) of factorial patterns with two treatment factors. The first factor is that the $N A A$ consists of 5 concentration levels $A_{0}(O M) A_{1}\left(10^{-7} \mathrm{M}\right), A_{2}\left(10^{-6} \mathrm{M}\right), A_{3}\left(5 \times 10^{-7} \mathrm{M}\right)$ and $A_{4}\left(5 \times 10^{-6}\right.$ $M)$ and the second factor is that corn seed extract of 5 levels concentratio $B_{0}(0 \%), B_{1}(2,5 \%), B_{2}$ $(5 \%) ; B_{3}(7,5 \%)$ and $B_{4}(10 \%)$. The administration NAA and corn seed extract in combination has a real effect on all parameters namely the number shoots, the number leaves, and the height shoots. The best results where the average number of shoots in the treatment of $A_{2}+B_{2}$ namely $5 \times 10^{-6} \mathrm{MNAA}+$ $10 \%$ corn seed extract. The best results average number of leaves in the treatment $A_{2}+B_{2}$ namely $5 \times 10^{-7} M N A A+5 \%$ corn seed extract and in the best results for shoot height in the treatment of $A_{1}+B_{1}$ namely $10^{-7} \mathrm{MNAA}+2.5 \%$ corn seed extract.

Keywords: Multiplication; black orchid's shoot; corn seed extract; NAA 


\section{PENDAHULUAN}

Anggrek hitam (Coelogyne pandurata Lindl.) merupakan anggrek khas Kalimantan termasuk dalam famili Orchidaceae. Famili ini mempunyai 800 genus dan 25000 spesies salah satunya Anggrek hitam yang memiliki karakter unik dan langka, yaitu pada bagian mahkota bunga berwarna hijau dan warna hitam pada bagian lidah atau labellum (Hartati 2015). Anggrek hitam dapat dikembangbiakkan dengan teknik konvensional.

Perkembangbiakkan secara vegetatif dengan cara stek menggunakan bagianbagian dari tanaman, namun untuk memperoleh tanaman dalam jumlah banyak cara ini kurang menguntungkan karena diperlukan waktu lama (Hendrayono 2000). Perkembangbiakan secara generatif dilakukan dengan menggunakan biji. Anggrek memiliki biji yang sebagian besar telah mengurangi endosperm dan menyebabkan biji anggrek membutuhkan proses simbiosis mutualisme dengan jamur mikoriza (Semiarti 2010). Salah satu alternatif untuk perbanyakan anggrek hitam dengan jumlah yang banyak, seragam, serta waktu yang relatif singkat yaitu dengan teknik kultur jaringan (Prasetyo 2009). Salah satu tahap yang dilakukan dalam kultur jaringan in vitro untuk dapat menyediakan anakan baru secara cepat dalam jumlah banyak yaitu dengan teknik multiplikasi tunas (Hendaryono dan Wijayani 2012).

Keberhasilan dalam teknik kultur in vitro dipengaruhi beberapa faktor yaitu, komposisi media tanam yang mengandung unsur hara makro, mikro, vitamin dan penambahan zat pengatur tumbuh (ZPT) yang sesuai dengan jenis eksplan dan tujuan kultur (Conger 1980). Penggunaan ZPT berfungsi sebagai hormon yang membantu proses pertumbuhan tanaman seperti pembelahan dan pemanjangan sel, serta diferensiasi jaringan (Gunawan 1998).

Zat pengatur tumbuh (ZPT) dapat diperoleh dari senyawa organik maupun sintetik. Salah satu sumber ZPT organik adalah ekstrak biji jagung. Ekstrak jagung mengandung asam amino, karbohidrat, vitamin, serta hormon zeatin yang dapat memenuhi unsur hara yang diperlukan oleh tanaman (Damiska et al. 2015). Auksin sintetik yang umum digunakan dalam kultur in vitro adalah Naphthalene Acetic Acid (NAA). Penambahan ZPT auksin dan sitokinin yang sesuai dapat membantu pertumbuhan tanaman anggrek secara in vitro.

Penggunaan ZPT sintetik juga dapat dipakai bersama-sama dengan ZPT organik atau bahan organik. NAA merupakan golongan auksin yang memiliki fungsi dalam menginduksi pemanjangan sel dan inisiasi pengakaran (Suryowinoto 1996). Penambahan bahan organik yang mengandung ZPT serta vitamin diketahui dapat memperbaiki pertumbuhan tanaman yang diperbanyak melalui kultur jaringan (Zulkarnain 2011). Kombinasi ZPT organik dengan ZPT sintetik diharapkan dapat menghasilkan pertumbuhan dan multiplikasi tunas anggrek $C$. pandurata dengan baik. Penelitian ini bertujuan untuk membuktikan pengaruh pemberian NAA (Naphthalene Acetic Acid) dan ekstrak biji jagung (Zea mays) terhadap multiplikasi tunas anggrek hitam (C. pandurata).

\section{METODE}

\section{Alat dan Bahan}

Alat yang digunakan adalah autoklaf, pinset, $\mathrm{pH}$ indikator, pisau skalpel, blender, botol kultur beserta tutup, bunsen, cawan petri, gelas ukur, hot plate, Laminar Air Flow Cabinet, magnetic stirer, pipet ukur, saringan, spatula, gelas beaker, dan timbangan analitik. Bahan yang digunakan adalah Anggrek hitam hasil kultur yang diperoleh dari UPTD Agribisnis Aloe Vera Center Pontianak, agar, akuades, alkohol $70 \%$, ekstrak biji jagung, gula pasir, larutan stok, media Murasshige dan Skoog (MS), dan NAA.

\section{Rancangan Percobaan}

Penelitian menggunakan Rancangan Acak Lengkap (RAL) pola faktorial dengan 2 faktor yaitu faktor konsentrasi ZPT NAA (A) yang terdiri dari 5 taraf konsentrasi yaitu 
$\mathrm{A}_{0}(0 \mathrm{M} /$ kontrol $) \mathrm{A}_{1}\left(10^{-7} \mathrm{M}\right), \mathrm{A}_{2}\left(10^{-6} \mathrm{M}\right)$, $\mathrm{A}_{3}\left(5 \times 10^{-7} \mathrm{M}\right)$ dan $\mathrm{A}_{4}\left(5 \times 10^{-6} \mathrm{M}\right)$. Faktor ekstrak biji jagung (B) dengan 5 taraf konsentrasi yaitu $\mathrm{B}_{0}(0 \%), \mathrm{B}_{1}(2,5 \%), \mathrm{B}_{2}$ $(5 \%) ; \mathrm{B}_{3}(7,5 \%)$ dan $\mathrm{B}_{4}(10 \%)$. Masingmasing perlakuan diulang sebanyak 3 kali.

\section{Pembuatan dan sterilisasi media}

Pembuatan media dilakukan dengan cara menimbang gula pasir sebanyak 30gr yang dimasukan ke dalam gelas beaker berukuran $500 \mathrm{ml}$, kemudian ditambahkan akuades 200 $\mathrm{ml}$, diaduk dengan magnetic stirer sampai gula larut. Selanjutnya dipipet larutan stok $\mathrm{A}, \mathrm{B}, \mathrm{C}, \mathrm{D}, \mathrm{E}, \mathrm{G}$ dan $\mathrm{H}$ masing-masing sebanyak $10 \mathrm{ml}$, dan larutan stok F sebanyak $1 \mathrm{ml}$ ke dalam gelas beaker. Agar-agar dimasukkan ke dalam gelas beaker dan ditambahkan akuades $500 \mathrm{ml}$, lalu dipanaskan hingga mendidih. Setelah mendidih, larutan stok hara, larutan gula, dan larutan agar-agar dimasukkan ke dalam gelas beaker $1000 \mathrm{ml}$, setelah itu digenapkan dengan akuades hingga volume $800 \mathrm{ml}$.

Selanjutnya media dibagi menjadi 4 bagian dengan volume masing-masing sebanyak $200 \mathrm{ml}$, ditambah NAA dan ekstrak jagung sesuai perlakuan, selanjutnya volume masing-masing media perlakuan ditepatkan menjadi $250 \mathrm{ml}$ dengan penambahan akuades. Kemudian diukur $\mathrm{pH}$ larutan hingga $\mathrm{pH}$ berkisar 5-6. Setelah itu media disterilisasi menggunakan autoklaf pada suhu $121^{\circ} \mathrm{C}$ dan tekanan 2 atm selama 20 menit.

\section{Penanaman Eksplan}

Kegiatan penanaman eksplan dilakukan di dalam LAFC. Eksplan yang digunakan yaitu tunas anggrek hitam in vitro. Eksplan yang berada di dalam botol kultur dikeluarkan dan diletakkan pada cawan petri yang berisi kertas saring, tunas-tunas dipisahkan, kemudian dimasukkan pada botol media. Setiap botol ditanam dua tunas anggrek hitam. Botol-botol kultur yang berisi eksplan diberi label tanggal penanaman dan perlakuan, kemudian disimpan ke ruang inkubasi

\section{ParameterPengamatan}

Parameter yang diamati yaitu rerata jumlah tunas (buah), rerata jumlah daun (helai), dan rerata tinggi tunas $(\mathrm{cm})$.

\section{HASIL DAN PEMBAHASAN \\ Rerata Jumlah Tunas}

Berdasarkan hasil ANAVA, pemberian NAA tunggal $(\rho=0,000)$ dan interaksi NAA + ekstrak biji jagung $(\rho=0,002)$ berpengaruh nyata terhadap jumlah tunas anggrek hitam. Perlakuan ekstrak jagung tunggal $(\rho=0,079)$ tidak berpengaruh nyata terhadap jumlah tunas anggrek hitam (Tabel 1 dan Gambar $1)$.

Tabel 1. Rerata jumlah tunas anggrek hitam setelah penambahan NAA dan ekstrak biji jagung pada kultur berumur 12 minggu

\begin{tabular}{|c|c|c|c|c|c|}
\hline \multirow{2}{*}{$\begin{array}{l}\text { NAA } \\
\text { (M) }\end{array}$} & \multicolumn{4}{|c|}{ Ekstrak Biji Jagung (\%) } & \multirow[b]{2}{*}{$\begin{array}{c}\mathrm{B}_{4} \\
(10)\end{array}$} \\
\hline & $\begin{array}{l}\mathrm{B}_{0} \\
(0)\end{array}$ & $\begin{array}{c}\mathrm{B}_{1} \\
(2,5)\end{array}$ & $\begin{array}{l}\mathrm{B}_{2} \\
(5)\end{array}$ & $\begin{array}{c}\mathrm{B}_{3} \\
(7,5)\end{array}$ & \\
\hline $\mathrm{A}_{0}(0)$ & $1^{\mathrm{a}}$ & $3,3^{\mathrm{ab}}$ & $3,6^{\mathrm{ab}}$ & $4^{\mathrm{abc}}$ & $2,6^{\mathrm{ab}}$ \\
\hline $\mathrm{A}_{1}\left(10^{-7}\right)$ & $1^{\mathrm{a}}$ & $2^{\mathrm{ab}}$ & $2,3^{\mathrm{ab}}$ & $3^{\mathrm{ab}}$ & $3,6^{\mathrm{ab}}$ \\
\hline $\mathrm{A}_{2}\left(5.10^{-7}\right)$ & $9,6^{\mathrm{d}}$ & $5^{\mathrm{bc}}$ & $5,3^{\mathrm{bc}}$ & $5,3^{\mathrm{bc}}$ & $3,6^{\mathrm{ab}}$ \\
\hline$A_{3}\left(10^{-6}\right)$ & $1^{\mathrm{a}}$ & $2^{\mathrm{ab}}$ & $\underset{\mathrm{c}}{3,6^{\mathrm{ab}}}$ & $5,3^{b c}$ & $\frac{3,6^{\mathrm{ab}}}{\mathrm{c}}$ \\
\hline $\mathrm{A}_{4}\left(5.10^{-6}\right)$ & $1^{\mathrm{a}}$ & $5,3^{\mathrm{bc}}$ & $5,3^{\mathrm{bc}}$ & $5,3^{\mathrm{bc}}$ & $7,3^{\text {cd }}$ \\
\hline
\end{tabular}

Keterangan: Faktor A, AxB berbeda nyata dan faktor B tidak bebeda nyata. Angkaangka pada setiap baris dan kolom yang diikuti oleh huruf kecil yang sama menunjukkan hasil yang tidak berbeda nyata berdasarkan uji lanjut duncan pada taraf $5 \%$



Gambar 1. Jumlah tunas anggrek Coelogyne pandurata pada perlakuan $\mathrm{A}_{4}+\mathrm{B}_{4}$ (Ket. Gambar 1: A. Akar, B. Tunas, C. Daun) 
Jumlah tunas merupakan parameter yang menggambarkan pertambahan banyaknya tunas yang terbentuk selama masa kultur. Hasil menunjukkan bahwa pemberian NAA tunggal berpengaruh nyata terhadap parameter jumlah tunas anggrek hitam dan memperlihatkan rerata tertinggi yaitu pada perlakuan $\mathrm{A}_{2} \mathrm{~B}_{0}\left(5 \times 10^{-7} \mathrm{M}\right.$ NAA $)$ dengan rerata jumlah tunas 9,66. Hal ini diduga bahwa NAA yang diberikan pada eksplan tunas anggek hitam perlakuan $\mathrm{A}_{2} \mathrm{~B}_{0}$ sudah sesuai dengan yang dibutuhkan oleh anggrek hitam dan dapat berinteraksi dengan ZPT endogen sehingga dapat mengubah rasio auksin-sitokinin endogen jaringan untuk menginduksi tunas baru. Hasil ini didukung oleh George dan Sherrington (1984) yang menyatakan bahwa auksin yang diberikan secara tunggal akan berinteraksi dengan ZPT endogen didalam tanaman untuk memacu pembelahan sel. Hasil penelitian Panjaitan (2005) menyatakan bahwa pemberian NAA konsentrasi $0,75 \mathrm{mg} / \mathrm{l}$ menghasilkan rerata jumlah tunas tertinggi pada minggu kedelapan setelah tanam yaitu 1,75 tunas dan pemberian NAA berpengaruh sangat nyata terhadap jumlah tunas yang terbentuk, tinggi tanaman dan jumlah akar tetapi berpengaruh tidak nyata terhadap jumlah daun planlet tanaman anggrek (Dendrobium sp.) secara in vitro.

Perlakuan kombinasi dari hasil statistik berpengaruh nyata terhadap rerata jumlah tunas dan pada perlakuan $\mathrm{A}_{4} \mathrm{~B}_{4}\left(5 \times 10^{-6} \mathrm{M}\right.$ $\mathrm{NAA}+10 \% \mathrm{EBJ})$ tidak berbeda nyata dengan perlakuan NAA tunggal $\mathrm{A}_{2} \mathrm{~B}_{0}\left(5 \times 10^{-7} \mathrm{M}\right.$ NAA) dengan rerata jumlah tunas yaitu 7,33 tunas. Hasil ini diduga NAA dan ekstrak biji jagung pada konsetrasi $\mathrm{A}_{4} \mathrm{~B}_{4}$ sudah berimbang dan dapat bekerja secara sinegis dalam pembentukan tunas anggrek hitam. NAA sebagai auksin berperan dalam mengatur pertumbuhan dan pemanjangan sel serta ekstrak biji jagung mengandung sitokinin yang berperan dalam pembelahan sel. Hal ini sesuai pendapat Maryani (2005) yang menunjukkan bahwa sitokinin dan auksin berperan saling melengkapi dalam menginduksi tunas Krisan.
Yuniastuti et al. (2010) menyatakan dalam pertumbuhan kultur tanaman kerja auksin dan sitokinin dalam perimbangan yang tepat akan menghasilkan pertumbuhan sel. Auksin dapat merangsang sel-sel primordial tunas dan memacu diferensiasi, sedangkan sitokinin berpengaruh terhadap inisiasi tunas. Menurut Lestari (2011), dalam proses pertumbuhan, sitokinin bersamasama dengan auksin memberikan pengaruh interaksi terhadap deferensiasi jaringan. Menurut Wattinema et al. (1992), penambahan sitokinin dalam media tumbuh kultur jaringan berperan dalam proses pembelahan sel, merangsang pembentukan tunas, memacu morfogenesis, pembentukan tunas lateral, dan perluasan permukaan daun yang dihasilkan dari pembelahan sel.

\section{Rerata jumlah Daun}

Berdasarkan hasil ANAVA bahwa pemberian NAA tunggal $(\rho=0,000)$ ekstrak jagung tunggal $(\rho=0,000)$ dan interaksi NAA + ekstrak biji jagung $(\rho=0,002)$ berpengaruh nyata terhadap jumlah daun anggrek hitam (Tabel 2 dan Gambar 2).

Tabel 2. Rerata jumlah daun (helai) anggrek hitam setelah penambahan NAA dan ekstrak biji jagung pada kultur berumur 12 minggu

\begin{tabular}{|c|c|c|c|c|c|}
\hline \multirow{2}{*}{$\begin{array}{c}\text { NAA } \\
\text { (M) }\end{array}$} & \multicolumn{5}{|c|}{ Ekstrak Biji Jagung (\%) } \\
\hline & $\begin{array}{l}\mathrm{B}_{0} \\
(0) \\
\end{array}$ & $\mathrm{B}_{1}(2,5)$ & $\mathrm{B}_{2}(5)$ & $\mathrm{B}_{3}(7,5)$ & $\mathrm{B}_{4}(10)$ \\
\hline & $1,6^{\mathrm{a}}$ & $10^{\text {bcde }}$ & $8,6^{\text {bcde }}$ & $9^{\text {bcde }}$ & $5^{a b}$ \\
\hline $\begin{array}{l}A_{1} \\
\left(10^{-7}\right)\end{array}$ & $1,6^{\mathrm{a}}$ & $6^{\mathrm{abc}}$ & $9,3^{\text {bcde }}$ & $7^{\mathrm{abcd}}$ & $7^{\mathrm{abcd}}$ \\
\hline $\begin{array}{l}\mathrm{A}_{2} \\
\left(5.10^{-7}\right)\end{array}$ & $\underset{\mathrm{e}}{12,3}$ & $9^{\text {bcde }}$ & $11,6^{\mathrm{de}}$ & $11,6^{\mathrm{de}}$ & $9,3^{\text {bcde }}$ \\
\hline $\begin{array}{l}\mathrm{A}_{3} \\
\left(10^{-6}\right)\end{array}$ & $1,6^{\mathrm{a}}$ & $2,6^{\mathrm{a}}$ & $11,6^{\mathrm{de}}$ & $10,3^{\text {bcde }}$ & $6^{\mathrm{abc}}$ \\
\hline $\begin{array}{l}\mathrm{A}_{4} \\
\left(5.10^{-6}\right)\end{array}$ & $2,6^{\mathrm{a}}$ & $10^{\text {bcde }}$ & $5,3^{\mathrm{ab}}$ & $6,3^{\mathrm{abcd}}$ & $11,3^{\text {cde }}$ \\
\hline
\end{tabular}

Keterangan: Faktor A, B dan AxB berbeda nyata. Angka-angka pada setiap baris dan kolom yang diikuti oleh huruf kecil yang sama menunjukkan hasil yang tidak berbeda nyata berdasarkan uji lanjut duncan pada taraf $5 \%$. 


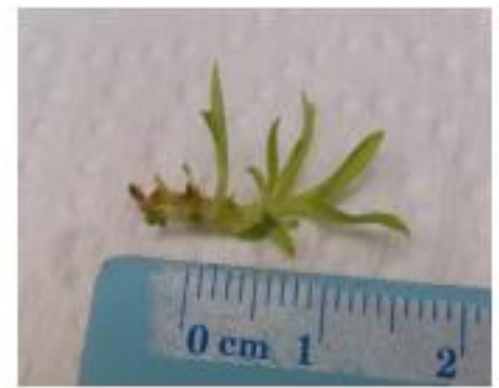

Gambar 2. Jumlah daun anggrek
$\begin{aligned} & \text { Coelogyne pandurata pada } \\ & \text { perlakuan } \mathrm{A}_{3}+\mathrm{B}_{0}\end{aligned}$

Hasil pengamatan jumlah daun menunjukkan bahwa perlakuan $\mathrm{A}_{2} \mathrm{~B}_{0}$ sudah mampu menginduksi pembentukan daun baru, terlihat dari rerata jumlah daun yang dihasilkan yaitu 12,33 helai. Hal ini menunjukan bahwa sitokinin yang ada di dalam jaringan anggrek hitam sudah cukup sehingga dengan penambahan hormon auksin eksogen pada konsentrasi $\mathrm{A}_{2} \mathrm{~B}_{0}$ dapat memicu proses diferensiasi dengan menginduksi pembentukan daun baru. Auksin yang diberikan diduga dapat berinteraksi dengan sitokinin endogen untuk merangsang pembentukan daun anggrek hitam. Hal ini diperkuat oleh pernyatan Basri \& Muslimin (2001) bahwa efektifitas ZPT sitokinin maupun auksin eksogen bergantung pada konsentrasi ZPT endogen yang ada pada jaringan tanaman.

Pemberian kombinasi NAA+ ekstrak biji jagung dari hasil analisis berpengaruh nyata terhadap rerata jumlah daun. Hasil statistik menunjukkan beberapa perlakuan kombinasi NAA+ekstrak biji jagung tidak berbeda nyata dengan perlakuan jagung tunggal konsentrasi $\mathrm{A}_{2} \mathrm{~B}_{0}$, diantaranya adalah perlakuan kombinasi pada konsentrasi $\mathrm{A}_{2} \mathrm{~B}_{2}, \mathrm{~A}_{2} \mathrm{~B}_{3}$, dan $\mathrm{A}_{3} \mathrm{~B}_{2}$ dengan rerata jumlah daun 11,66 helai. Hal ini menunjukan terjadinya interaksi antara ZPT eksogen berupa NAA dan ekstrak biji jagung sehingga mampu untuk memicu pertumbuhan daun baru pada anggrek hitam. Arnita (2008) menjelaskan sitokinin dan auksin bekerja sama untuk memacu pembelahan sel dan mempengaruhi diferensiasi sel. Sitokinin yang diberikan secara tunggal tidak mempunyai pengaruh, tetapi apabila sitokinin diberikan secara bersama-sama dengan auksin maka sel tersebut dapat membelah.

Ekstrak biji jagung yang diberikan pada eksplan tunas anggrek hitam diduga dapat mengubah rasio sitokinin di dalam jaringan anggrek hitam sehingga dapat berinteraksi dengan NAA untuk memacu pertumbuhan daun pada anggrek hitam. Hal ini diperkuat oleh Kasutjianingati et al. (2013) bahwa penambahan zeatin pada media dapat mendorong meningkatnya jumlah daun pada eksplan tunas pisang saat rasio sitokinin yang lebih tinggi dibandingkan auksin. Hasil penelitian Febryantiet et al. (2017), yang menunjukan jumlah daun eksplan anggrek Dendrobium heterocarpum Lindl. terbanyak dihasilkan pada media kombinasi $50 \mathrm{~g}$ jagung hibrida + NAA 0,1 mg/L.

\section{Rerata Tinggi Tunas}

Berdasarkan hasil ANAVA pemberian NAA tunggal $(\rho=0.104)$ dan ekstrak jagung tunggal $(\rho=0.624)$ tidak berpengaruh nyata terhadap tinggi tunas. Sedangkan perlakuan interaksi NAA + ekstrak biji jagung $(\rho=0.009)$ berpengaruh nyata terhadap tinggi tunas anggrek hitam (Tabel 3 dan Gambar $3)$.

Tabel 3. Rerata tinggi tunas anggrek hitam setelah penambahan NAA dan ekstrak biji jagung pada kultur berumur 12 minggu

\begin{tabular}{lccccc}
\hline \multicolumn{1}{c}{$\begin{array}{c}\text { NAA } \\
(\mathrm{M})\end{array}$} & \multicolumn{5}{c}{ Ekstrak Biji Jagung (\%) } \\
\cline { 2 - 6 } & $\mathrm{B}_{0}$ & $\mathrm{~B}_{1}$ & $\mathrm{~B}_{3}$ & $\mathrm{~B}_{4}$ & $\mathrm{~B}_{5}$ \\
& $(0)$ & $(2,5)$ & $(5)$ & $(7,5)$ & $(10)$ \\
\hline $\mathrm{A}_{0}(0)$ & $\mathbf{2 , 5}^{\mathrm{d}}$ & $1,8^{\mathrm{abcd}}$ & $1,4^{\mathrm{abc}}$ & $1,4^{\mathrm{abc}}$ & $1,4^{\mathrm{abc}}$ \\
$\mathrm{A} 1\left(10^{-7)}\right.$ & $1,1^{\mathrm{a}}$ & $1,9^{\mathrm{cd}}$ & $1,8^{\mathrm{abcd}}$ & $1,6^{\mathrm{abc}}$ & $1,7^{\mathrm{abcd}}$ \\
$\mathrm{A}_{2}\left(5.10^{-7}\right)$ & $1,6^{\mathrm{abc}}$ & $1,6^{\mathrm{abc}}$ & $1,8^{\mathrm{abcd}}$ & $1,8^{\mathrm{abcd}}$ & $1,8^{\mathrm{abcd}}$ \\
$\mathrm{A}_{3}\left(10^{-6}\right)$ & $1,1^{\mathrm{abc}}$ & $1,8^{\mathrm{abcd}}$ & $1,7^{\mathrm{abc}}$ & $1,63^{\mathrm{abc}}$ & $1,8^{\mathrm{abcd}}$ \\
$\mathrm{A}_{4}\left(5.10^{-6}\right)$ & $1,5^{\mathrm{abc}}$ & $1,5^{\mathrm{abc}}$ & $1,1^{\mathrm{ab}}$ & $1,6^{\mathrm{abc}}$ & $1,2^{\mathrm{abc}}$ \\
\hline
\end{tabular}

Keterangan: Faktor A, AxB berbeda nyata dan faktor B tidak berbeda nyata. Angka-angka pada setiap baris dan kolom yang diikuti oleh huruf kecil yang sama menunjukkan hasil yang tidak berbeda nyata berdasarkan uji lanjut duncan pada taraf $5 \%$. 


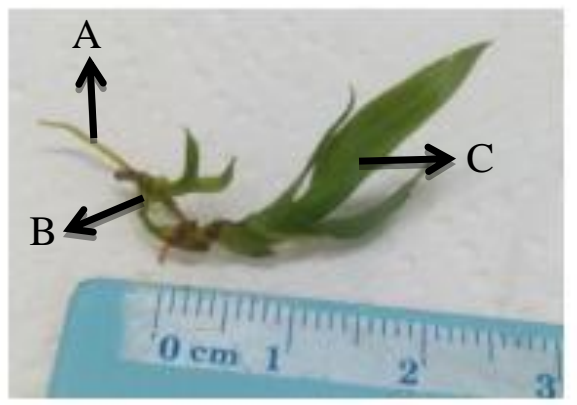

Gambar 3. Tinggi tunas anggrek Coelogyne pandurata pada perlakuan $\mathrm{A}_{1}+\mathrm{B}_{1}$ (A. Akar, B.Tunas, C. Daun)

Rerata tinggi tunas anggrek hitam pada perlakuan kontrol yaitu $2,5 \mathrm{~cm}$, tidak berbeda nyata dengan beberapa perlakuan lain salah satunya perlakuan kombinasi $\mathrm{A}_{1} \mathrm{~B}_{1}$ dengan rerata $1,93 \mathrm{~cm}$. Rerata tinggi tunas terbaik pada kontrol diduga ZPT endogen di dalam jaringan anggrek hitam sudah ada dalam keadaan berimbang untuk memicu pembelahan dan pemanjangan sel sehingga terjadi penambahan tinggi tunas. Namun saat dilakukan penambahan ZPT eksogen berupa NAA dan ekstrak biji jagung secara kombinasi pada konsentrasi tertentu juga dapat memicu tinggi tunas anggrek hitam, salah satunya pada perlakuan $\mathrm{A}_{1} \mathrm{~B}_{1}$. Hasil penelitian ini sejalan dengan hasil penelitian kartiman et al. (2018) pada parameter tinggi tanaman anggrek hitam menghasilkan rerata tertinggi pada media MS tanpa penambahan ZPT (kontrol) namun tidak berbeda nyata dengan media tanpa NAA yang ditambahkan BAP.

Pemberian NAA tunggal dan ekstrak biji jagung tunggal tidak memberi pengaruh nyata terhadap parameter tinggi tunas. Hal ini dikarenakan auksin di dalam jaringan anggrek hitam sudah cukup tinggi sehingga dengan penambahan auksin eksogen secara tunggal tidak memberi pengaruh nyata terhadap tinggi tunas anggrek hitam. Interaksi antara NAA atau ekstrak biji jagung dengan ZPT endogen menghasilkan rasio auksin dan sitokinin yang tidak berimbang sehingga dapat menghambat pertumbuhan tinggi tunas anggrek hitam. Menurut Pisesha (2008) tingginya respon jaringan untuk tumbuh, tergantung pada kemampuan auksin dan sitokinin yang ditambahkan kedalam media untuk merubah ZPT endogen dalam sel. Hasil penelitian yang dilakukan Febryanti et al. (2017) pada tanaman anggrek Dendrobium heterocarpum Lind. menyatakan bahwa penambahan NAA yang lebih dari $0,1 \mathrm{mg} / \mathrm{L}$ justru menghasilkan tinggi tunas yang lebih pendek. Menurut Tuhuteru et al., (2012) respon yang muncul pada eksplan tanaman tergantung kemampuan eksplan tersebut dalam menyerap ZPT eksogen dari media tumbuh dan menggunakannya dengan ZPT endogen yang ada didalam tanaman.

Perlakuan kombinasi NAA+ekstrak biji jagung berpengaruh nyata terhadap tinggi tunas anggrek hitam. Hal ini diduga pemberian ZPT eksogen auksin dan sitokinin dapat berinteraksi dan bekerja secara sinergis dalam pertumbuhan tinggi tunas anggrek hitam. Menurut Salisbury (1995), pertumbuhan panjang tunas dipengaruhi oleh hormon auksin dan sitokinin. Sitokinin akan merangsang pembelahan sel melalui peningkatan laju sinetsis protein, sedangkan auksin akan memacu pamanjangan sel-sel, sehingga menyebabkan pemanjangan batang. Mekanisme kerja auksin dalam mempengaruhi pemanjangan sel-sel tanaman yaitu auksin memacu protein tertentu yang ada di membran plasma sel tumbuhan untuk memompa ion $\mathrm{H}^{+}$kedinding sel. Ion $\mathrm{H}^{+}$ mengaktifkan enzim ekspansin sehingga memutuskan beberapa ikatan silang hidrogen rantai molekul selulosa penyusun dinding sel. Sel tumbuhan kemudian memanjang akibat air yang masuk secara osmosis. Setelah pemanjangan, sel terus tumbuh dengan mensintesis kembali material dinding sel dan sitoplasma yang merupakan peranan dari sitokinin.

\section{KESIMPULAN}

Kesimpulan dari penelitian ini adalah pemberian NAA dan ekstrak biji jagung secara kombinasi berpengaruh nyata terhadap semua parameter yaitu jumlah tunas, jumlah daun, dan tinggi tunas. Perlakuan $\mathrm{A}_{4}+\mathrm{B}_{4}$ menunjukkan hasil terbaik 
pada parameter rerata jumlah tunas. Parameter rerata jumlah daun pada perlakuan $\mathrm{A}_{2}+\mathrm{B}_{2}$ menunjukkan hasil terbaik dan pada perlakuan $\mathrm{A}_{1}+\mathrm{B}_{1}$ ekstrak biji jagung menunjukkan hasil terbaik untuk parameter tinggi tunas.

\section{DAFTAR PUSTAKA}

Arnita R (2008) Pengaruh Konsentrasi Sitokinin dan Takaran Pupuk Organik Terhadap Pertumbuhan dan Hasil Pule Pandak (Rauvolfia serpentine (L.) Benth. Ex Kurz), Skripsi, Fakultas Pertanian Universitas Sebelas Maret, Surakarta.

Basri Z dan Muslimin (2001) Pengaruh Sitokinin Terhadap Organogenesis Krisan Secara In Vitro, Jurnal Agroland Vol.5, No 4, hal:164-170.

Conger BV (1980) Cloning agricultural plants via in vitro technique. CRC Press Inc. Florida.

Damiska SRS, Wulandari dan Darwati $\mathrm{H}$ (2015) Penambahan Ragi dan Ekstrak Biji Jagung Terhadap Pertumbuhan Tunas Manggis Secara In Vitro, Jurnal Hutan Lestari Vol.3, No.1, hal:11.

Febryanti Ni Luh Putu Kayika, Made Ria Defiani, Ida Ayu Astarini (2017) Induksi Pertumbuhan Tunas Dari Eksplan Anggrek Dendrobium Heterocarpum Lindl. Dengan Pemberian Hormon Zeatin Dan Naa, Jurnal Metamorfosa Vol.4, No.1, hal:41-4.

George EF dan Sherrington PD, 1984, Plant Propagation by Tissue Culture, Handbook and Directory of Commercial Laboratories, Exegetic, England, 709 p.

Gunawan LW (1998) Teknik Kultur Jaringan Tumbuhan, Institut Pertanian Bogor, Bogor,

Hartati S (2015) Analisis Keragaman Genetik Tetua dan Hasil PersilanganAnggrek Hitam (Coelogyne pandurata Lindl.), Jurnal of Biotechnologi and Biodiversity, Vol.1, No.1, hal: 26-30.

Hendaryono DPS dan Wijayani A (1994) Teknik Kultur Jaringan Pengenalan dan
Petunjuk Perbanyakan Tanaman Secara Vegetatif Modern, Kanisius, Yogyakarta.

Kartiman RD, Sukma SI, Aisyah dan A Purwito (2018) Multiplikasi In vitro Anggrek hitam (Coelogyne pandurata Lindl.) pada perlakuan kombinasi NAA dan BAP, jurnal Bioteknologi dan Biosains Indonesia Vol.5, No.1, hal: 7587.

Kasutjianingati dan Irawan R (2013) Media alternative perbanyakan in-vitro anggrek bulan (Phalaenopsis amabilis), Jurnal agroteknos Vol.1, No.3, hal:184-189.

Maryani, Yekti dan Zamroni (2005) Penggandaan Tunas Krisan Melalui Kultur Jaringan, Ilmu Pertanian, Vol.12, No.1, hal: 51-55.

Panjaitan E (2005) Renspon pertumbuhan tanaman anggrek (Dendrobium sp.) terhadap Pemberian BAP dan NAA secara in vitro, Jurnal Penel. Bid, Ilmu Pert Vol.3, No.3, hal:45-51.

Pisesha PA (2008) Pengaruh Konsentrasi IAA, IBA, BAP, dan Air Kelapa Terhadap Pembentukan Akar Poinsettia (Euphorbia pulcherrima Will Et Klotzch), Secara In Vitro, Skripsi, Bogor Institut Pertanian Bogor.

Pramesti G (2011) SPSS 18,0 dalam Rancangan Percobaan, PT, Elex Media Kumputindo, Jakarta.

Prasetyo LB dan Zulkifli MS (2009) Mendorong Konservasi yang Bermanfaat Bagi Masyarakat Lokal, Newsletter Cifor, Riak Bumi.

Salisbury, Frank B dan Cleon W Ross (1995) Fisiologi Tumbuhan Jilid 1. Bandung: ITB.

Semiarti E, Indrianto A dan SuyonoEA, (2010) Genetic trasnfortion of The Indonesia Black Orchid (Coelogyne pandurata Lindl.) Though Agrobacterium tumefaciens for Micropopagation, jaournal Proceeding of NICO, Nagoya Dome, Japan Vol.10,No.2, hal:16-20.

Suryowinoto (1996) Pemuliaan Tanaman Secara In vitro, Yogyakarta: Kanisius 
Tuhuteru S (2012) Pertumbuhan dan Perkembangan Anggrek Dendrobium Anosmum Pada Media Kultur In Vitro Dengan Beberapa Konsentrasi Air Kelapa, JurnalAgrologia Vol.1, No.1, hal:84-86.

Wattimena GA, Gunawan LW, Mattjik NA, Syamsudin E, Wiendi, dan Erniawati A (1992) Bioteknologi Tanaman, Laboratorium Kultur Jaringan Tanaman Pusat Antar Universitas Bioteknologi IPB, Bogor.
Yuniastuti E, Praswanto dan Harminingsih I (2010) Pengaruh Konsentrasi BAP Terhadap Multipikasi Tunas Anthurium (Anthurium andraeanum Linden) pada Beberapa Media Dasar Secara In vitro, Jurnal Caraka Tani XXV Vol.3, No.1, hal:2-7.

Zulkarnain H (2011) Kultur Jaringan Tanaman: Solusi perbanyakan tanaman budi daya, Penebar Swadaya. 